\title{
Association between Epicardial Adipose Tissue Thickness and Left Ventricular Diastolic Functions
}

\author{
Epikardiyal Yağ Doku Kalınlığı ile Sol Ventrikül Diyastolik \\ Fonksiyonları Arasındaki İlişki
}

\author{
Sabiye Yllmaz ${ }^{1}$, Saadet Demirtaş ${ }^{2}, K$ ahraman Coşansu ${ }^{1}$, Hüseyin Gündüz ${ }^{1}$, Harun Kılıç ${ }^{1}$ \\ ${ }^{1}$ Department of Cardiology, Sakarya University Education and Research Hospital, Faculty of Medicine, Sakarya, Turkey \\ ${ }^{2}$ Department of Cardiology, Ankara Dışkapı Yıldırım Beyazıt Eğitim ve Araştırma Hastanesi
}

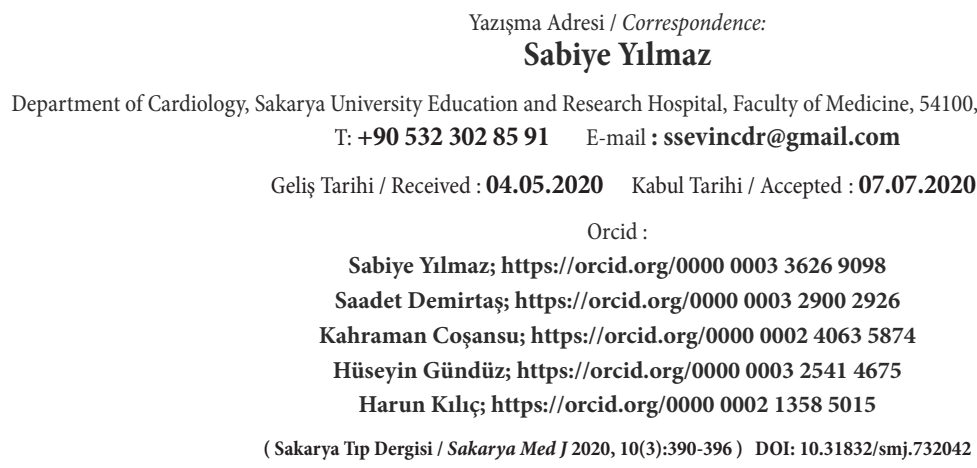

\footnotetext{
Abstract

Objective Epicardial adipose tissue (EAT) has been found to be associated with the diastolic dysfunction in recent years, but this relationship has not been fully elucidated. Echocardiography is a non-invasive, simple, cost effective and accessible approach to assess EAT thickness, which can be performed easily. The aim of this study was to evaluate the effectiveness of EAT on prediction of diastolic dysfunction.

Materials A total of 138 patients without any cardiovascular, inflammatory, autoimmune and cancer disease, were enrolled. Our study was performed in the Cardiology clinic of and Methods Sakarya University Training and Research Hospital between May 2019 and December 2019. Subjects were divided into two groups, those with and without diastolic dysfunctions. Conventional echocardiography parameters and tissue Doppler imaging (TDI) were performed to evaluate left ventricular functions. EAT thickness on the free wall of the right ventricle in parasternal long-axis view were measured using transthoracic echocardiography.

Results In comparison with the non- diastolic dysfunction group, patients with diastolic dysfunction had significantly higher epicardial fat thickness $(5.98 \pm 1.52 \mathrm{~mm}$ vs $4.32 \pm 1.03$ $\mathrm{mm} ; \mathrm{p}<0.001)$. The multivariate regression analysis indicated that EAT independently predicts diastolic dysfunction $(\mathrm{OR}, 0.278,95 \% \mathrm{CI} 0.396$ to 1.400$)$

Conclusion According to the findings of this study, EAT thickness is an independent predictor for the development of diastolic dysfunction in patients without cardiovascular disease.

Keywords Adipose tissue; echocardiography; epicardium; left ventricular function

$\ddot{\mathrm{O} z}$

Amaç Epikardiyal yağ dokusunun (EYD) son yıllarda diyastolik disfonksiyon ile ilişkili olduğu bulunmuștur, ancak bu ilișki tam olarak aydınlatılamamıştır. Ekokardiyografi, EYD kalınlı̆̆ını değerlendirmek için kolayca yapılabilen non-invaziv, basit, uygun maliyetli ve erişilebilir bir yaklaşıımdır. Bu çalışmanın amacı EYD’nin diyastolik disfonksiyonun öngörülmesindeki etkinliğini değerlendirmekti.

Gereçve Herhangi bir kardiyovasküler, inflamatuar, otoimmün ve kanser hastallğı olmayan toplam 138 hasta çalışmaya dahil edildi. Çalışmamız xxxx Üniversitesi Eğitim ve Araştırma Hastanesi

Yöntemler Kardiyoloji kliniğinde Mayıs 2019 ve Aralık 2019 tarihleri arasında gerçekleștirildi. Calıșmaya alınan kișiler diyastolik disfonksiyonu olan ve olmayanlar olmak üzere iki gruba ayrıldı. Sol ventrikül fonksiyonların değerlendirmek için konvansiyonel ekokardiyografi parametreleri ve doku Doppler görüntüleme (DD) yapıldı. EYD kalınlğı parasternal uzun eksen görünümünde sağ ventrikülün serbest duvarı önünden transtorasik ekokardiyografi kullanılarak ölçüldü.

Bulgular Diyastolik disfonksiyonu olmayan grup ile karşılașttrıldı̆̆ında, diyastolik disfonksiyonu olan hastalarda epikardiyal yağ kalınlğı̆ anlamlı olarak daha yüksekti (5.98 \pm 1.52 mm’ye karşı 4.32 \pm 1.03 mm; $p<0.001)$. Çok değişkenli regresyon analizi, EYD’nn diyastolik disfonksiyonu bağımsız olarak öngördüğünü gösterdi (OR, 0.278,\% 95 CI 0.396 ila 1.400)

Sonuç Buçalıșmanın bulgularına göre, EYD kalınly̆ı kardiyovasküler hastalığı olmayan hastalarda diyastolik disfonksiyon gelișimi için bağımsız bir öngördürücüdür. 


\section{INTRODUCTION}

Left ventricular diastolic dysfunction is one of the most important causes of heart failure though systolic functions are preserved. ${ }^{1,2}$ The diagnosis of diastolic dysfunction remains challenging and practical recommendations are necessary for proper diagnosis in daily clinical practice. Although many echocardiographic parameters have been used to define diastolic dysfunction, there is no single marker to confirm the diagnosis sufficiently accurate. Epicardial fat depot is a part of the visceral adipose tissue and metabolically active with release of different cytokines and plays an important role in the development of cardiovascular diseases through paracrine and vasocrine mechanisms. ${ }^{1-9}$ The Epicardial adipose tissue (EAT) thickness is defined based on the measurement of the low-isoechoic area thickness on the free wall of the right ventricle in the parasternal long-axis views by echocardiography. ${ }^{10}$ EAT has been found to be associated with the diastolic dysfunction in recent years, but this relationship has not been fully elucidated. The aim of this study was to evaluate the effectiveness of EAT thickness on prediction of diastolic dysfunction.

\section{MATERIAL and METHODS}

Study Design and Population

This was a cross sectional, single-center study conducted in department of Cardiology, Sakarya University Education and Research Hospital from the May 2019 to December 2019. In the present study, consecutive 138 patients admitted to cardiology outpatient clinic for echocardiographic evaluation were included. Study population was divided into two groups as those with and without diastolic dysfunction by echocardiography. Patients with coronary artery disease, systolic heart failure, arrhythmias, moderate-severe valvular heart disease, hematological disease, cancer, severe renal or liver disease, ongoing infection or systemic inflammatory conditions, autoimmune disease, transient ischemic attacks/stroke and whose transthoracic echocardiography (TTE) imaging was inadequate for the measurement of epicardial fat thickness were excluded from the study. Data on the patients' demographic characteristics incluiding age, sex, body mass index (BMI), comorbidities such as hypertension, diabetes mellitus and laboratory findings were recorded.

TTE was performed using Vivid S710 ultrason with a 5 $\mathrm{MHz}$ transducer in left lateral decubitus position in all patients to measure EAT, to evaluate systolic and diastolic left ventricular function. Measurements of the interventricular septum (IVS) thickness, left ventricular posterior wall (LVPW) thickness, left ventricular end diastolic diameter (LVEDD) and left ventricular mass (LVM) were performed according to the American Society of Echocardiography criteria. ${ }^{11,12}$ The early (E) and late(A) transmitral inflow velocities, their ratio (E/A) were obtained from the mitral inflow Doppler signals. ${ }^{13,14}$ EAT thickness was measured on the free wall of the right ventricule in the parasternal long-axis taking the aortic root as the reference and we prefer measuring EFT during end-diastole. ${ }^{10}$ Epicardial fat was defined as the echo-free space between the outer wall of the myocardium and the visceral layer of the pericardium. Left ventricular systolic function was determined using ejection fraction measured by Simpson's method. ${ }^{15}$ Additionally, tissue Doppler imaging (TDI) was performed to evaluate diastolic functions in each patient. Mitral annulus velocities were achieved from the septal annulus of the LV by TDI, ratio of E/e' were calculated. The measurement of EAT thickness was performed by two different cardiologists, and was performed at least twice to ensure high reliability. This study complies with the Helsinki Declaration and was approved by Sakarya University Education and Research Hospital independent medical ethics committee on 20.06.2019 with the number 16214662 / 050.01 .04 / 103.

\section{Statistical analysis}

Statistical analyses were performed with the Statistical Package for the Social Sciences (SPSS), version 18 software (SPSS Inc., Chicago, IL, USA). Categorical data were expressed as percentages and continuous data were 
expressed as mean \pm standard deviation. Comparisons between groups were performed using a chi-square or Fisher's exact tests for qualitative variables. An independent t-test was used for normally distributed continuous variables, and the Mann-Whitney $U$ test was conducted for non-normally distributed continuous variables, as appropriate. The cutoff values, and corresponding sensitivity and specificity values, for the prediction of diastolic dysfunction by echocardiographic EAT thickness was estimated by receiving operator characteristic (ROC) curve analysis. Multivariate logistic regression analysis was performed to assess the independent predictors of diastolic dysfunction. The variables showing significant relationship in the univariate analysis were selected for the multivariate logistic regression analysis for the prediction of diastolic dysfunction. Results are reported as odds ratio (OR) with 95\% confidence interval (CI). A p value $<0.05$ was considered statistically significant in all tests.

\section{RESULTS}

A total of 138 patients were enrolled and subjects were divided into two groups, those with diastolic dysfunction $(n=64)$ and without diastolic dysfunction $(n=58)$ on echocardiography. The patient characteristics of both groups are shown in Table 1 . The patients with diastolic dysfunction were older $(57.7 \pm 9.8$ vs $44.1 \pm 8.5, \mathrm{p}<0.001)$, more likely female (53.1\% vs $44.8 \%$ ), and had more comorbidites including diabetes mellitus, hypertension and had increased BMI. There was no significant difference between the groups with respect to low-density lipoprotein cholesterol (LDL-C), triglycerides (TG) and high-density lipoprotein cholesterol (HDL-C) levels. There was a significant difference between the two groups in terms of C-reactive protein (CRP) level. The diastolic dysfunction group had thicker EAT thickness than the non- diastolic dysfunction group $(5.98+1.52 \mathrm{~mm}$ vs $4.32+1.03 \mathrm{~mm}, \mathrm{p}<0.001)$.

\begin{tabular}{|c|c|c|c|}
\hline Variable & $\begin{array}{c}\text { Diastolic } \\
\text { dysfunction } \\
\text { group, } \\
(\mathbf{n}=64)\end{array}$ & $\begin{array}{c}\text { Non-Diastolic } \\
\text { dysfunction } \\
\text { group } \\
(\mathbf{n}=58)\end{array}$ & $\mathbf{p}$ \\
\hline Age, mean \pm SD (years) & $57.7 \pm 9.8$ & $44.1 \pm 8.5$ & $<0.001$ \\
\hline Female, n (\%) & $34(53)$ & $26(44.8)$ & 0.364 \\
\hline Diabetes mellitus, $\mathrm{n}(\%)$ & $10(15.6)$ & 0 & 0.001 \\
\hline Hypertension,n(\%) & $34(53.1)$ & $4(6.9)$ & $<0.001$ \\
\hline Smoking,n(\%) & $17(26.6)$ & $23(39.7)$ & 0.126 \\
\hline $\mathrm{EAT}(\mathrm{mm})$, mean $\pm \mathrm{SD}$ & $5.98 \pm 1.52$ & $4.32 \pm 1.03$ & $<0.001$ \\
\hline $\begin{array}{l}\text { BMI }(\mathrm{kg} / \mathrm{m} 2) \\
\text { mean } \pm \text { SD }\end{array}$ & $30.1 \pm 4.7$ & $25.6 \pm 3.5$ & $<0.001$ \\
\hline $\mathrm{CRP}$ mean $\pm \mathrm{SD}$ & $3.2 \pm 3.8$ & $1.5 \pm 3.3$ & 0,019 \\
\hline $\begin{array}{l}\mathrm{LDL}(\mathrm{mg} / \mathrm{dl}) \\
\text { mean } \pm \mathrm{SD}\end{array}$ & $148 \pm 42$ & $147 \pm 36$ & 0.856 \\
\hline $\begin{array}{l}\mathrm{HDL}(\mathrm{mg} / \mathrm{dl}) \\
\text { mean } \pm \mathrm{SD}\end{array}$ & $48 \pm 12$ & $49 \pm 13$ & 0.829 \\
\hline $\mathrm{TG}(\mathrm{mg} / \mathrm{dl})$, mean $\pm \mathrm{SD}$ & $154 \pm 77$ & $161 \pm 127$ & 0.740 \\
\hline $\mathrm{EF}$, mean $\pm \mathrm{SD}$ & $61 \pm 4$ & $63 \pm 6$ & 0.006 \\
\hline $\mathrm{E}$, mean $\pm \mathrm{SD}$ & $59.6 \pm 12$ & $74.8 \pm 12$ & $<0.001$ \\
\hline $\mathrm{A}$, mean $\pm \mathrm{SD}$ & $77.7 \pm 15$ & $65 \pm 10$ & $<0.001$ \\
\hline $\mathrm{e}^{\prime}(\mathrm{cm} / \mathrm{s})$, mean $\pm \mathrm{SD}$ & $7.06 \pm 1.2$ & $9.8 \pm 1.7$ & $<0.001$ \\
\hline $\mathrm{a}^{\prime}(\mathrm{cm} / \mathrm{s})$, Mean $\pm S D$ & $9.86 \pm 2$ & $9.9 \pm 1.9$ & 0.959 \\
\hline $\mathrm{E} / \mathrm{e}^{\prime}$, mean $\pm \mathrm{SD}$ & $9.1 \pm 3$ & $7.8 \pm 1.5$ & 0.009 \\
\hline $\begin{array}{l}\text { LVEDD }(\mathrm{mm}) \\
\text { mean } \pm \text { SD }\end{array}$ & $42.4 \pm 4.3$ & $40.4 \pm 6.1$ & 0.044 \\
\hline IVST $(\mathrm{mm})$, mean \pm SD & $11.1 \pm 1.7$ & $9.8 \pm 1.7$ & $<0.000$ \\
\hline $\mathrm{PWT}(\mathrm{mm})$, mean $\pm \mathrm{SD}$ & $10.8 \pm 1.1$ & $9.8 \pm 1.1$ & $<0.000$ \\
\hline $\operatorname{LVM}(\mathrm{g})$, mean $\pm \mathrm{SD}$ & $182.5 \pm 40.6$ & $152.8 \pm 37.7$ & $<0.000$ \\
\hline \multicolumn{4}{|l|}{$\begin{array}{l}\text { Diastolic function, } \\
\mathrm{n}(\%)\end{array}$} \\
\hline Grade I & $58(90.6 \%)$ & & \\
\hline Grade II & $6(9.4 \%)$ & & \\
\hline Grade III & 0 & & \\
\hline \multicolumn{4}{|c|}{$\begin{array}{l}\text { A-late transmitral inflow velocities, BMI-Body Mass Index, CRP- C-reac- } \\
\text { tive protein, DD-diastolic dysfunction, EAT- adipose tissue, E-early trans- } \\
\text { mitral inflow velocities, e-early diastolic myocardial velocity, EF- ejection } \\
\text { fraction, HDL- high-density lipoprotein, LDL-low-density lipoprotein, } \\
\text { LVM-left ventricular mass, LVEDD-left ventricular end diastole diameter, } \\
\text { IVST- interventricular septum thickness, PWT-posterior wall thickness, } \\
\text { TG- triglycerides }\end{array}$} \\
\hline
\end{tabular}

EAT thickness showed a significant positive correlation with age $(\mathrm{r}=0.479, \mathrm{p}<0.001)$, BMI $(\mathrm{r}=0.538, \mathrm{p}<0.001)$, diabetes mellitus $(\mathrm{r}=0.353, \mathrm{p}<0.001)$ and hypertension $(\mathrm{r}=0.380, \mathrm{p}<0.001)$. There was no correlation between ep- 
icardial fat thickness and HDL-C, LDL-C and TG level. Also, EAT was associated with increased left ventricular mass $(\mathrm{r}=0.399, \mathrm{p}<0.001)$ and reduced diastolic function by lower early diastolic myocardial velocity (e') ( $r=-0.595$, $\mathrm{p}<0.001)$, early transmitral inflow velocity $(\mathrm{E})(\mathrm{r}=-0.399$, $\mathrm{p}<0.001), \mathrm{E} / \mathrm{A}(\mathrm{r}=-0.505, \mathrm{p}<0.001)$ and higher $\mathrm{E} / \mathrm{e}^{\prime}$ ratio $(\mathrm{r}=0.316, \mathrm{p}<0.001)$ (Table 2).

Table 2: Correlation of Epicardial adipose tissue thickness with clinical variables

\begin{tabular}{|l|c|c|}
\hline & $\mathrm{p}$ & $\mathrm{r}$ \\
\hline Age & $<0.001$ & 0.479 \\
\hline BMI & $<0.001$ & 0.538 \\
\hline
\end{tabular}

BMI

Hypertension

Diabetes mellitus

Smoking

CRP

HDL

LDL

TG

EF

E

E/A

$\mathrm{e}^{\prime}$

E/e'

IVST

PWT

LVEDD

LVM

\begin{tabular}{l|l}
$<0.001$ & 0.538 \\
$<0.001$ & 0.380 \\
\hline
\end{tabular}

A-late transmitral inflow velocities, BMI-Body Mass Index, CRP- C-reactive protein, DD-diastolic dysfunction, EAT- adipose tissue, E-early transmitral inflow velocities, e-early diastolic myocardial velocity, EF- ejection fraction, HDL- high-density lipoprotein, LDL-low-density lipoprotein, LVM-left ventricular mass, LVEDD-left ventricular end diastole diameter IVST- interventricular septum thickness, PWT-posterior wall thickness, TG- triglycerides

Multivariate analysis showed that age (OR, 0.376, 95\%CI, 0.009 to 0.024 ), hypertension (OR, $0.194 ; 95 \% \mathrm{CI}, 0.043$ to 0.375 ), diabetes (OR, 0.284; 95\%CI,0.011 to 0.420), BMI (OR, 0.201; 95\%CI, 0.000 to 0.036) and LVM (OR, 0.181; 95\%CI,0.000 to 0.004 ) were independent factors affecting diastolic dysfunction. Also multivariate analysis revealed that thick EAT was a predictor of diastolic dysfunction
(OR, 0.225, 95\%CI 0.191 to 1.270 ) after adjustment for covariates, including diabetes, hypertension, age, BMI (Table 3).

Table 3. Correlation of clinical quantitative variables with diastolic dysfunction and predictors of diastolic dysfunction determined by multi-linear regression analysis.

\begin{tabular}{|l|c|c|c|c|}
\hline & $\mathrm{p}$ & $\mathrm{R}$ & $\mathrm{OR}$ & $\mathrm{CI}$ \\
\hline EAT & $<0.001$ & 0.534 & 0.225 & $0.191-1.270$ \\
\hline Age & $<0.001$ & 0.594 & 0.376 & $0.009-0.024$ \\
\hline Hypertension & $<0.001$ & 0.499 & 0.194 & $0.043-0.375$ \\
\hline BMI & $<0.001$ & 0.477 & 0.201 & $0.000-0.036$ \\
\hline Diabetes mellitus & 0.001 & 0.284 & 0.118 & $0.011-0.422$ \\
\hline E/A & $<0.001$ & -0.760 & -0.573 & $-1.372-(-0.769)$ \\
\hline E/e' & 0.009 & 0.239 & 0.278 & $0.031-0.083$ \\
\hline LVM & 0.002 & 0.290 & 0.181 & $0.000-0.004$ \\
\hline A-l tran & & & &
\end{tabular}

A-late transmitral inflow velocities, BMI-Body Mass Index, CRP- C-reactive protein, DD-diastolic dysfunction, EAT- adipose tissue, E-early transmitral inflow velocities, e-early diastolic myocardial velocity, EF- ejection fraction, HDL- high-density lipoprotein, LDL-low-density lipoprotein, LVM-left ventricular mass, LVEDD-left ventricular end diastole diameter, IVST- interventricular septum thickness, PWT-posterior wall thickness,

TG- triglycerides

The area under the curve on receiver operating characteristic (ROC) analysis of EAT thickness for predicting diastolic dysfunction was 4.9 with a sensitivity of $75 \%$ and specificity of $73 \%$ (ROC area $0.820, \mathrm{P}<0.001,95 \% \mathrm{CI}, 0.746$ to 0.893 ) (figure 1).

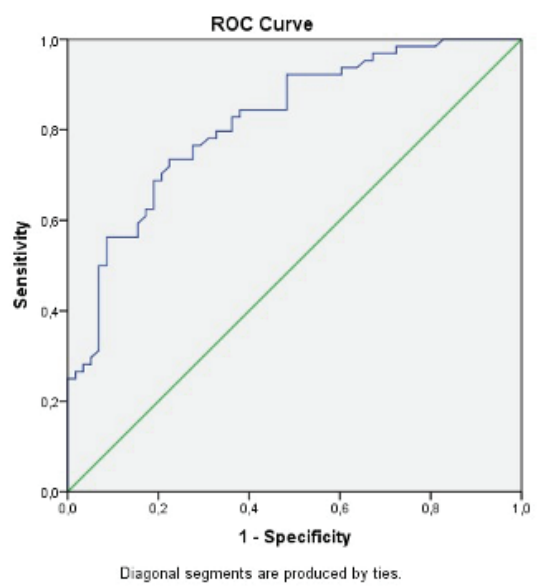

Figure 1. ROC curve (Receiver operating characteristic curve) illustrating the accuracy of epicardial adipose tissue thickness for diastolic dysfunction 


\section{DISCUSSION}

Although EAT thickness is still controversial in the evaluation of cardiovascular function, it seems to be a promising marker in the evaluation of cardiovascular and metabolic risks in daily clinical practice. Left ventricular diastolic dysfunction is the main underlying pathophysiology of heart failure with preserved ejection fraction. ${ }^{1,2}$ Early detection of impared LV diastolic function is clinically important because $\mathrm{LV}$ diastolic dysfunction is related to poor clinical outcomes. ${ }^{2}$ The measurement of EAT with other classical echocardiographic parameters may be useful in the detection of LV diastolic dysfunction.

Previous studies have shown; EAT is a part of visceral adipose tissue localized between the heart and pericardium and it is a metabolically active fat depot. ${ }^{3-10}$ Excessive epicardial adipose tissue accumulation has been suggested to play an important role in the development of cardiovascular disease through potential endocrine or paracrine mechanism by exerting inflammatory mediators. ${ }^{3-10}$ These factors may alter cardiac structure and result in impaired myocardial relaxation, reduced diastolic compliance, and elevated LV filling pressures. ${ }^{16,17}$ Consequently, these studies suggested that EAT may lead to LV hypertrophy, left atrium (LA) dilation, diastolic and systolic dysfunction, irrespective of the presence of coronary artery disease (CAD). ${ }^{16-21}$ Consistent with these findings, CRP, an inflammatory marker, was higher in the patient with diastolic dysfunction and was associated with increased EAT thickness in our study.

Patients included in our study had low cardiovascular risk profile and had no systemic inflammatory disease. Patients with diastolic dysfunction had more comorbidity including diabetes, hypertension and they had higher BMI than patients without diastolic dysfunction. As known, all of these comorbidities and obesity can cause diastolic dysfunction and associated with increased EAT thickness. ${ }^{19,22,23}$ Like Tae and et al. study, EAT thickness has been found to be less influenced by cholesterol levels in the present study. ${ }^{23}$ Along with the previous evidence, the present study confirms that there is a significant correlation between the EAT and LV diastolic dysfunction independent of other traditional risk factors incluidindg diabetes, hypertension and obesity. $22-26$

In fact, obesity itself is a risk factor for the development of diastolic heart failure, independent of other co-morbidities. ${ }^{27,28}$ In our study, patients with diastolic dysfunction had higher BMI but consistent with other studies, EAT thickness was associated with the presence of diastolic dysfunction independent of BMI in our population..$^{29-31}$ Hence, it is likely that even in nonobese subjects, EAT may influence myocardial remodeling adversely.

Like other studies, we observed effect of EAT on LV hypertrophy and LV diastolic dysfunction. ${ }^{32-34}$ EAT thickness are related to predictors of diastolic function such as ratio of E/A, E/e, septal e velocity in the present study and can be easily measured by TTE as additive diagnostic marker for diastolic function.

Many studies on EAT have reported different cut-off values of EAT thickness in different diseases and different ethnic groups. In our study, the cut-off value of EAT thickness was determined to be approximately $4.9 \mathrm{~mm}$. So EAT thickness (of $4.9 \mathrm{~mm}$ or more) may identify an individual with higher probability of having diastolic dysfunction in Turkish population. In addition, in larger patient series, EAT thickness can be evaluated separately for systolic and diastolic heart failure to investigate whether it has prognostic significance.

\section{Study Limitations}

The major limitation of this study was the small sample size. A prospective study is needed to determine the predictive value of EAT thickness with high patient population. Another major limitation of the study is that; EAT measurement by echocardiography is economical, easily available, and non-invasive method, but it is not an ide- 
al method for assessment of adipose tissue due to a linear measurement at a single location. However the EAT volume measured by computed tomography (CT) has not previously demonstrated a superior predictive value over the EAT thickness as measured by echocardiography. ${ }^{35}$

\section{CONCLUSION}

The measurement of echocardiographic EAT thickness seems to be an acceptable method which can be used as an easily, cost affectively, and non-invasively. Increased EAT thickness is independently associated with diastolic dysfunction. Adding EAT measurement on top of classic echocardiographic diastolic dysfunction findings may provide further evidence in predicting diastolic dysfunction in daily clinical practice. But large, more definitive studies are needed to confirm these findings

\section{Conflict of Interest}

There is no conflict of interest to be declared.

\section{Authors' contributions}

All authors contributed to this project and article equally. All authors readand approved the final manuscript

\section{Ethical approval}

This study complies with the Helsinki Declaration and was approved by Sakarya University Education and Research Hospital independent medical ethics committee on 20.06.2019 with the number 16214662 / 050.01.04 / 103.

\section{Funding}

This research received no grant from any funding agency in the public, commercial or not-for-profit sectors. 
Sakarya Med J 2020;10(3):390-396

YILMAZ et al., Epicardial Adipose Tissue Thickness and Diastolic Functions

\section{References}

1. Lam CS, Donal E, Kraigher-Krainer E, Vasan RS. Epidemiology and clinical course of heart failure with preserved ejection fraction. Eur J Heart Fail 2011;13:18-28.

2. Halley CM, Houghtaling PL, Khalil MK, Thomas JD, Jaber WA. Mortality rate in patients with diastolic dysfunction and normal systolic function. Arch Intern Med 2011;171:1082-7.

3. Sacks HS, Fain JN. Human epicardial adipose tissue: a review. Am Heart J 2007; 153: 907 -917 .

4. Ouwens DM, Sell H, Greulich S, Eckel J. The role of epicardial and perivascular adipose tissue in the pathophysiology of cardiovascular disease. J Cell Mol Med 2010; 14: 2223-2234.

5. Venteclef N, Guglielmi V, Balse E, Gaborit B, Cotillard A, Atassi F, et al. Human epicardial adipose tissue induces fibrosis of the atrial myocardium through the secretion of adipo-fibrokines. Eur Heart J 2015; 36: 795-805a.

6. Park HK, Kwak MK, Kim HJ, Ahima RS. Linking resistin, inflammation, and cardiometabolic diseases. Korean J Intern Med 2017;32:239-247.

7. Iacobellis G. Local and systemic effects of the multifaceted epicardial adipose tissue depot. Nat Rev Endocrinol 2015;11:363-371.

8. Gaborit B, Sengenes C, Ancel P, Jacquier A, Dutour A. Role of Epicardial Adipose Tissue in Health and Disease: A Matter of Fat? Compr Physiol 2017; 7(3): 1051-82.

9. Talman AH, Psaltis PJ, Cameron JD, Meredith IT, Seneviratne SK, Wong DT. Epicardial adipose tissue: far more than a fat depot. Cardiovasc Diagn Ther 2014; 4(6): 416-29.

10. Bertaso AG, Bertol D, Duncan BB, Foppa M. Epicardial fat: definition, measurements and systematic review of main outcomes. Arq Bras Cardiol 2013; 101: e18-28.

11. Cheitlin MD, Armstrong WF, Aurigemma GP, Beller GA, Bierman FZ, Davis JL, et al. Guideline update for the clinical application of echocardiography: summary article. J Am Soc Echocardiogr 2003; 16: 1091-110

12. Devereux $R B$, Reichek $N$. Echocardiographic determination of left ventricular mass in man. Anatomic validation of the method. Circulation 1977; 55: 613-8

13. Nagueh SF, Appleton CP, Gillebert TC, Marino PN, Oh JK, Smiseth OA, et al. Recommendations for the evaluation of left ventricular diastolic function by echocardiography. J AmSocEchocardiogr 2009; 22:107-133.

14. Paulus WJ, Tschöpe C, Sanderson JE, RusconiC, Flachskampf FA, Rademakers FE, et al. How to diagnose diastolic heart failure: a consensus statement on the diagnosis of heart failure with normal left ventricular ejection fraction by the Heart Failure and Echocardiography Associations of the European Society of Cardiology. Eur Heart J 2007; 28: 2539-2550.

15. Schiller NB, Shah PM, Crawford M, DeMaria A, Devereux R, Feigenbaum H, et al. Recommendations for quantitation of the left ventricle by two-dimensional echocardiography. American society of Echocardiography Committee on Standards Subcommittee on Quantitation of Two-Dimensional Echocardiography. J Am Soc Echocardiogr 1989;2:358-67.

16. Fitzgibbons TP, Czech MP. Epicardial and perivascular adipose tissues and their influence on cardiovascular disease: basic mechanisms and clinical associations. J Am Heart Assoc 2014;3:e000582.

17. Shimabukuro M, Hirata Y, Tabata M, Dagvasumberel M, Sato H, Kurobe H, et al. Epicardial adipose tissue volume and adipocytokine imbalance are strongly linked to human coronary atherosclerosis. Arterioscler Thromb Vasc Biol 2013;33:1077- 1084.

18. Haffar T, Akoumi A, Bousette N. Lipotoxic palmitate impairs the rate of beta-oxidation and citric acid cycle flux in rat neonatal cardiomyocytes. Cell Physiol Biochem 2016;40:969-981.

19. Turak O, Ozcan F, Canpolat U, Isleyen A, Cebeci M, Oksuz F, et al. Increased echocardiographic epicardial fat thickness and high-sensitivity CRP level indicate diastolic dysfunction in patients with newly diagnosed essential hypertension. Blood Press Monit 2013;18:259-64.

20. Fontes-Carvalho R, Fontes-Oliveira M, Sampaio F, Mancio J, Bettencourt N, Teixeira M,et al. Influence of epicardial and visceral fat on left ventricular diastolic and systolic functions in patients after myocardial infarction. Am J Cardiol 2014; 114:1663-1669.
21. Ng ACT, Goo SY, Roche N, van der Geest RJ, Wang WYS. Epicardial adipose tissue volume and left ventricular myocardial function using 3-dimensional speckle tracking echocardiography. Can J Cardiol 2016;32:1485-1492

22. Fenk S, Fischer M, Strack C, Schmitz G, Loew T, Lahmann C, et al. Successful weight reduction improves left ventricular diastolic function and physical performance in severe obesity. Int Heart J 2015;56:196-202.

23. Tae-Min Rhee, Hack-Lyoung Kim, Woo-Hyun Lim, Jae-Bin Seo, Sang-Hyun Kim, Joo-Hee Zo, et al. Association between epicardial adipose tissue thickness and parameters of target organ damage in patients undergoing coronary angiography. Hypertension Research 2019; 42:549-557

24. Konishi M, Sugiyama S, Sugamura K, Nozaki T, Matsubara J, Akiyama E, et al. Accumulation of pericardial fat correlates with left ventricular diastolic dysfunction in patients with normal ejection fraction. J Cardiol 2012;59:344-51.

25. Cavalcante JL, Tamarappoo BK, Hachamovitch R, Kwon DH, Alraies MC, Halliburton S, et al. Association of epicardial fat, hypertension, subclinical coronary artery disease, and metabolic syndrome with left ventricular diastolic dysfunction. Am J Cardiol 2012;110:1793-8.

26. Iacobellis G, Leonetti F. Epicardial adipose tissue and insulin resistance in obese subjects. J Clin Endocrinol Metab 2005;90:6300-2.

27. Owan TE, Hodge DO, Herges RM, Jacobsen SJ, Roger VL, Redfield MM. Trends in prevalence and outcome of heart failure with preserved ejection fraction. N Engl J Med 2006; 355:251- 259.

28. Yancy CW, Jessup M, Bozkurt B, Butler J, Casey DE Jr, Drazner MH, et al. ACCF/AHA guideline for the management of heart failure: executive summary: a report of the American College of Cardiology Foundation/American Heart Association Task Force on practice guidelines. Circulation 2013; 128:1810-1852.

29. Lai YH, Hou CJY, Yun CH, Sung KT, Su CH, Wu TH, et al. The association among MDCT-derived three-dimensional visceral adiposities on cardiac diastology and dyssynchrony in asymptomatic population. BMC Cardiovasc Dis-ord 2015;15:142-153.

30. Fontes-Carvalho R, Fontes-Oliveira M, Sampaio F, Mancio J, Betten-court N, Teixeira M, et al. Influence of epicardial and visceral fat on left ventricular diastolic and systolic functions in patients after myocardial infarction. Am J Cardiol 2014;114:1663-1669.

31. Hung CL, Yun CH, Lai YH, Sung KT, Bezerra HG, Kuo JY, et al. An observational study of the association among interatrial adiposity by computed tomography measure, insulin resistance, and left atrial electromechanical disturbances in heart failure. Medicine 2016;95:e3912.

32. Jennifer Mancio, Diana Azevedo, Mariana Fragao-Marques, Ines Falcao-Pires, Adelino Leite-Moreira, Nuno Lunet, et al. Meta-Analysis of Relation of Epicardial Adipose Tissue Volume to Left Atrial Dilation and to Left Ventricular Hypertrophy and Functions. Am J Cardiol 2019;123:523-531

33. Fox CS, Gona P, Hoffmann U, Porter SA, Salton CJ, Massaro JM, et al. Pericardial fat, intrathoracic fat, and measures of left ventricular structure and function: the Framingham Heart Study. Circulation 2009;119:1586-1591.

34. Liu J, Fox CS, Hickson DA, May WL, Ding J, Carr JJ, et al. Pericardial fat and echocardiographic measures of cardiac abnormalities: the Jackson Heart Study. Diabetes Care 2011;34:341-346.

35. Wu FZ, Chou KJ, Huang YL, Wu MT. The relation of locationspecific epicardial adipose tissue thickness and obstructive coronary artery disease: systemic review and meta-analysis of observational studies. BMC Cardiovasc Disord 2014;14:62. 